\title{
Community ecology of parasites in four species of Corydoras (Callichthyidae), ornamental fish endemic to the eastern Amazon (Brazil)
}

\author{
MAKSON M. FERREIRA ${ }^{1}$, RAFAEL J. PASSADOR ${ }^{2}$ and MARCOS TAVARES-DIAS ${ }^{3}$ \\ ${ }^{1}$ Graduação em Ciências Biológicas, Faculdade de Macapá/FAMA, Rodovia \\ Duca Serra, s/n, Cabralzinho, 68906-801 Macapá, AP, Brazil \\ ${ }^{2}$ Instituto Chico Mendes de Conservação da Biodiversidade/ICMBio, Rua Leopoldo \\ Machado, 1126, Centro, 68900-067 Macapá, AP, Brazil \\ ${ }^{3}$ Embrapa Amapá, Rodovia Juscelino Kubitschek, 2600, 68903-419 Macapá, AP, Brazil \\ Manuscript received on April 2, 2018; accepted for publication on June 11, 2018
}

\begin{abstract}
How to cite: FERREIRA MM AND PASSADOR RJ. 2019. Community ecology of parasites in four species of Corydoras (Callichthyidae), ornamental fish endemic to the eastern Amazon (Brazil). An Acad Bras Cienc 91: e20170926. DOI 10.1590/0001-3765201920170926.
\end{abstract}

\begin{abstract}
This study compared the parasites community in Corydoras ephippifer, Corydoras melanistius, Corydoras amapaensis and Corydoras spilurus from tributaries from the Amapari River in State of Amapá (Brazil). A total of 151 fish of these four ornamental species were examined, of which $66.2 \%$ were parasitized by one or more species, and a total of 732 parasites were collected. Corydoras ephippifer $(91.2 \%)$ and C. spilurus $(98.8 \%)$ were the most parasitized hosts, while C. amapaensis $(9.6 \%)$ was the least parasitized. A high similarity $(\cong 75 \%)$ of parasite communities was found in the host species. Hosts were parasitized by Procamallanus (Spirocamallanus) inopinatus, Camallanus sp. and metacercariae of digeneans. The parasites had an aggregated dispersion pattern, but in C. ephippifer a random dispersion of P. (S.) inopinatus was found. The parasite community was characterized by a low species richness (1-4 parasites per host), low diversity and low evenness, and consisted mainly of endoparasites with high prevalence and low abundance. An important component in the determination of the helminth parasite community composition was the dominance of species that use these fish species as secondary intermediate or paratenic hosts. This was the first study on the parasite community for these four hosts. A checklist of parasite species in wild populations of Corydoras spp. from different localities was also reported here.
\end{abstract}

Key words: Amazon, diversity, helminths, parasites, freshwater fish.

\section{INTRODUCTION}

Corydoras Lacépède, 1803 (Callichthyidae) are siluriforms fish distributed in part of South and Central America, but they are most abundant in the Amazonas River basin. In general, Corydoras

Correspondence to: Marcos Tavares-Dias

E-mail: marcos.tavares@embrapa.br

ORCid: http://orcid.org/0000-0002-8376-1846 spp. are benthic fish living associated with sandy or muddy substrates of highly diversified habitats such as rivers, lakes, near to the banks or at shallow depths (Tencatt and Ohara 2016). Omnivorous fish, feed on invertebrates such as aquatic worms, microcrustaceans, insects, insect larvae and eggs, mollusks and possibly algae and plants (Froese and Pauly 2018). Several species of Corydoras have economic importance for the ornamental 
fish market (Rodríguez-Ithurralde et al. 2014). No species of Corydoras is listed as "Least Concern" by the IUCN.

Corydoras ephippifer Nijssen, 1972, Corydoras melanistius Regan, 1912, Corydoras amapaensis Nijssen, 1972 and Corydoras spilurus Norman, 1926, have endemic distribution in the eastern Amazon region. Corydoras ephippifer is found in some hydrographic basins in the state of Amapá (northern Brazil), while C. melanistius is distributed in basins from Suriname, French Guiana and some basins in the state of Amapá. Corydoras amapaensis is found in tributaries of the rivers Amapari and Oiapoque in the state of Amapá (Brazil), and in rivers from the French Guiana. Corydoras spilurus have distribution known in Approuagua River in French Guiana and Suriname River, in Suriname (Froese and Pauly 2018), but also in tributaries from the Amapari River in the state of Amapá.

The capture and transport of Amazonian wild ornamental fish can cause stress due to inadequate management, which can lead to parasitic infections and high mortality rates of host populations. These fish presents a peculiar fauna of parasites and when captured and kept in culture with high population density, they may present high rates of parasitic infections (Ferraz 1999, Tavares-Dias et al. 2010, Aguinaga et al. 2015, Hoshino et al. 2018). Parasites, an inseparable component of the environment, are often the major cause of mortality and elimination of fish by the ornamental fishery (Ferraz 1999, Tavares-Dias et al. 2010, Aguinaga et al. 2015), which represents high biological losses. Thus, considering the importance of parasites, studies on these organisms can serve as basis for a series of investigations, such as parasite-induced pathology, use of parasites as bioindicators of water quality, ecological and economic impacts caused by invasive species and their parasites, etc. (Ferraz and Sommerville 1998, Tavares-Dias et al. 2010, Mathews et al. 2015, Hoshino et al. 2018).
In addition, it is necessary to study the parasites in hosts of ecosystems that were not investigated previously. The aim of this study was to compare the parasite community of $C$. melanistius, $C$. ephippifer, C. amapaensis and C. spilurus, fish endemic to eastern Amazon (northern Brazil).

\section{MATERIALS AND METHODS}

\section{FISH AND COLLECTION AREA}

From July to December 2016, 52 Corydoras melanistius, 38 C. ephippifer, 31 C. amapaensis and 30 C. spilurus were collected in the Água Fria River (Figure 1), a tributary of the Amapari River basin, in the municipality of Pedra Branca do Amapari, state of Amapá (Brazil). For parasitological analysis, all fish were collected using hand nets because these tributaries of the Amapari River present large floodplain areas, with very peculiar characteristics, since they are strongly influenced by high rainfall in the Amazon region. These are then highly complex river systems and regulation is a process that affects the integrity of the riverfloodplain system. This study was developed in accordance with the principles recommended by the Colégio Brasileiro de Experimentação Animal (Cobea) and with the authorization from Comissão de Ética no Uso de Animais of the Embrapa Amapá (Number 005 - CEUA/CPAFAP) and SISBIO (Number 23276-1).

\section{COLLECTION AND ANALYSIS OF PARASITES}

Each fish was weighed (g) and measured for total length $(\mathrm{cm})$ and then necropsied for analysis and collection of ectoparasites and endoparasites. The mouth, gills, opercula and fins were examined for the presence of ectoparasites, and the viscera and gastrointestinal tract, for the presence of endoparasites. The collection, fixation, counting, preparation and staining of parasites for identification followed previous recommendations of Eiras et al. (2006). 

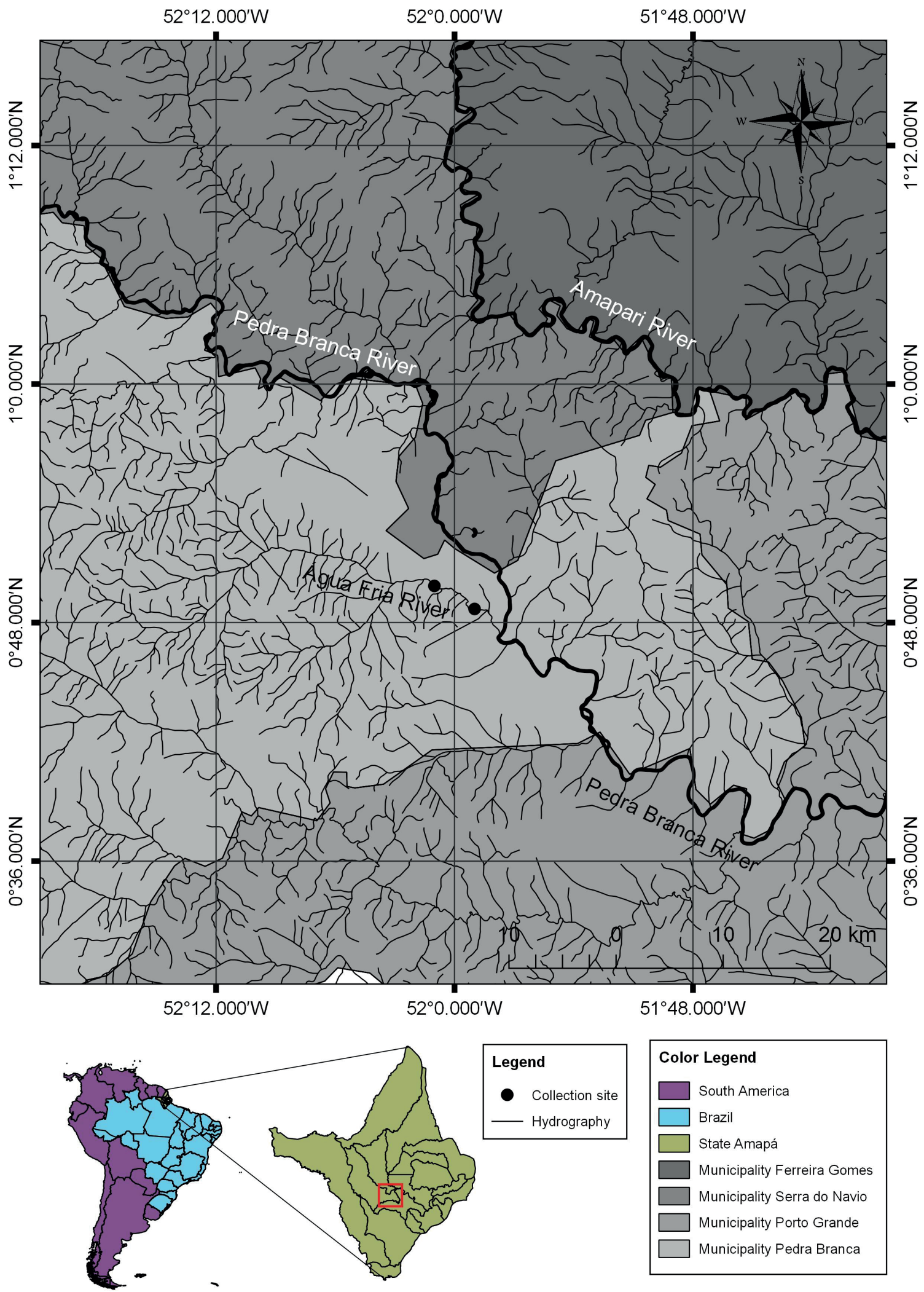

Figure 1 - Collection site of the four species of Corydoras endemic to the eastern Amazon (Brazil). 
The ecological terms used followed previous recommendations of Bush et al. (1997). The following descriptors for the parasite community were calculated: the species richness, the Shannon diversity index $(H)$, evenness $(E)$ in association with diversity index, and the Berger-Parker dominance index $(d)$ and dominance frequency (percentage of infracommunities in which a parasite species is numerically dominant) (Rohde et al. 1995, Magurran 2004), using the Diversity software (Pisces Conservation Ltd., UK). The dispersion index (ID) and discrepancy index (D) were calculated using the software Quantitative Parasitology 3.0, in order to detect the distribution pattern of parasite infracommunities (Rózsa et al. 2000), for species with prevalence $>10 \%$. The significance of ID, for each infracommunity, was tested using the $d$ - statistics (Ludwig and Reynolds 1988). The Spearman correlation coefficient ( $r s$ ) was used to determine possible correlations of length with parasite abundance, species richness, and Shannon diversity (Zar 2010).

To test the differences between the parasite communities of $C$. ephippifer, $C$. melanistius, $C$. amapaensis and $C$. spilurus, the ANOSIM test was applied with 999 permutations using the Jaccard (J) similarity index (presence/absence of species), and dissimilarity index of Bray-Curtis (B) (abundance) (Hammer et al. 2001).

\section{RESULTS}

In C. ephippifer, C. melanistius, C. amapaensis and $C$. spilurus, the total parasitic prevalence varied from 9.6 to $96.8 \%$, but C. ephippifer and C. spilurus were the hosts most parasitized, while C. amapaensis was the least parasitized (Table I). The nematodes Procamallanus (Spirocamallanus) inopinatus Travassos, Artigos \& Pereira and Camallanus Railliet and Henry, 1915 and encysted metacercariae of Digenea were common parasites for the four species of Corydoras and were the dominant parasites. Gyrodactylus von Nordmann, 1832 occurred only in C. ephippifer and pentastomid larvae occurred only in C. spilurus (Table II).

The parasites exhibited an aggregated dispersion pattern, but $P$. (S.) inopinatus had a random dispersion pattern in C. ephippifer (Table III).

The mean values of parasite species richness, Shannon diversity and evenness were lowest in C. amapaensis (Table IV). The body length of $C$. melanistius had no correlation with the Shannon diversity index $(r s=0.228, \mathrm{p}=0.115)$ and species richness of parasites $(r s=0.143, \mathrm{p}=0.326)$. The body length of $C$. ephippifer showed no correlation with the Shannon diversity index $(r s=0.008, \mathrm{p}$ $=0.965)$ and species richness of parasites $(r s=$ $-0.068, \mathrm{p}=0.699$ ).

The body length of $C$. ephippifer was not correlated with the abundance of $P$. (S.) inopinatus ( $r s=-0.212, \mathrm{p}=0.220)$, Camallanus sp. $(r s=-0.031$, $\mathrm{p}=0.860)$ and undetermined digenean metacercariae ( $r s=0.069, \mathrm{p}=0.693$ ). The length of $C$. melanistius showed no correlation with the abundance of $P$. (S.) inopinatus ( $r s=0.121, \mathrm{p}=0.408)$, Camallanus $\mathrm{sp}$. $(r s=0.068, \mathrm{p}=0.645)$ and undetermined digenean metacercariae ( $r s=0.221, \mathrm{p}=0.144)$. The length of C. spilurus showed no correlation with the abundance of $P$. (S.) inopinatus ( $r s=-0.260, \mathrm{p}=0.157)$ and Camallanus sp. ( $r s=-0.126, \mathrm{p}=0.498)$, but a weak correlation with the abundance of digenean metacercariae $(r s=-0.363, \mathrm{p}=0.044)$.

Similarity of component communities of host populations exhibited qualitative and quantitative homogeneity (Table V). ANOSIM detected no spatial difference in the composition and abundance of parasite species between populations of the four host species $\left(\mathrm{R}_{\text {Jaccard }}=0.112, \mathrm{p}=0.0001 ; \mathrm{R}_{\text {Bray-Curtis }}=\right.$ $0.196 ; \mathrm{p}=0.0001)$.

In C. melanistius and C. ephippifer, there was a predominance of hosts infected with one parasite species, while for $C$. amapaensis the predominance was of uninfected hosts and C. spilurus was of hosts infected with two species of parasites (Figure 2). 
TABLE I

Total parasitological indices in four species of Corydoras endemic to the eastern Amazon (Brazil).

\begin{tabular}{ccccc}
\hline Indices & C. ephippifer & C. melanistius & C. amapaensis & C. spilurus \\
\hline Examined fish & 38 & 52 & 31 & 30 \\
Parasitized fish & 35 & 38 & 3 & 24 \\
Prevalence (\%) & 91.2 & 73.1 & 9.6 & 96.8 \\
$\begin{array}{c}\text { Total number of } \\
\text { parasites }\end{array}$ & 221 & 127 & 6 & 378 \\
\hline
\end{tabular}
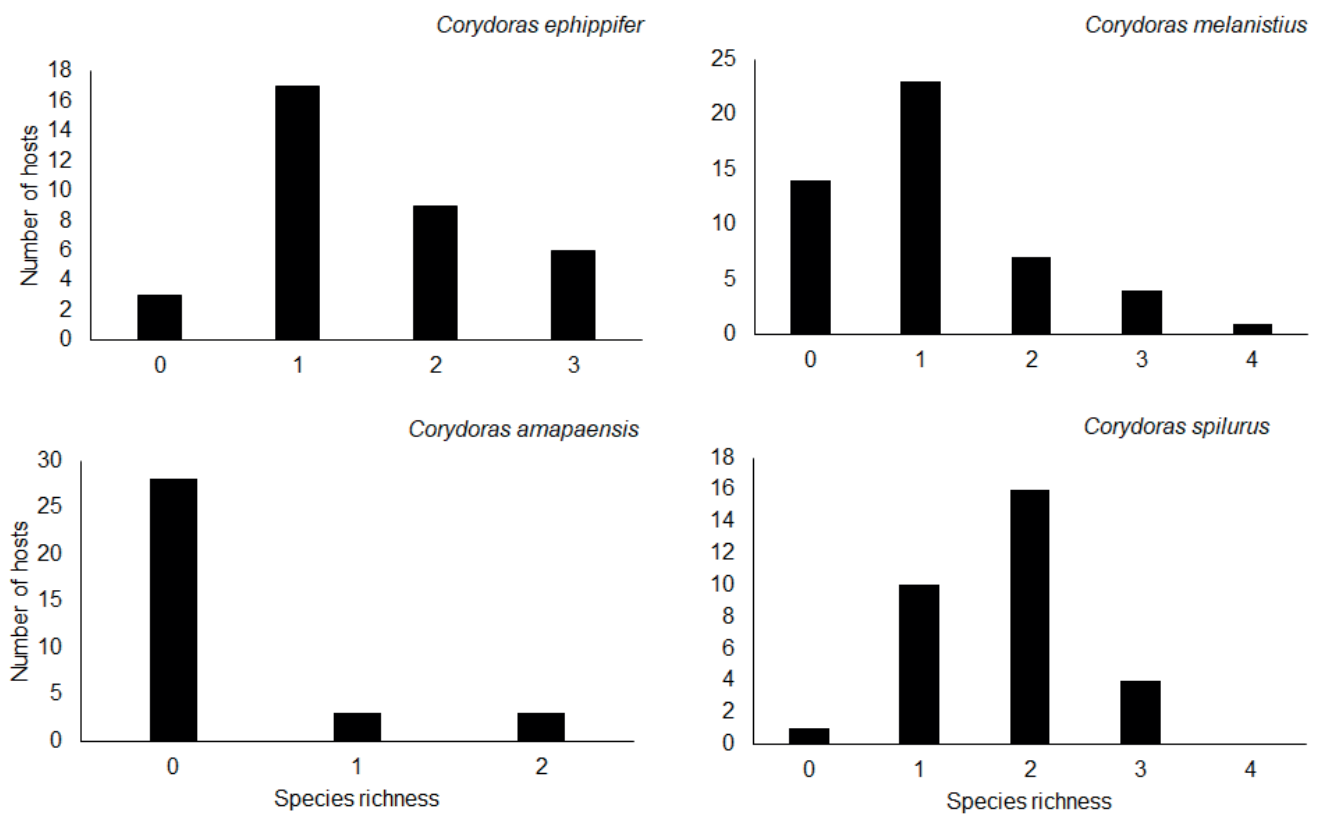

Figure 2 - Species richness of parasites for four species of Corydoras endemic to the eastern Amazon (Brazil).

\section{DISCUSSION}

Some species of parasites are known by infecting Corydoras spp. from different localities, of which 8 are species of Monogenea, 2 Nematoda, 3 Myxozoa, 2 Crustacea, 2 Protozoa and 2 Acanthocephala. Therefore, the dominance is of ectoparasites species (Table VI). However, none of these parasite species was found in C. ephippifer, C. melanistius, C. amapaensis and C. spilurus from the eastern Amazon. Thus, the parasite species found herein are the first records for these four host species from the eastern Amazon. In addition, for C. ephippifer, C. melanistius, C. amapaensis and C. spilurus, there was a dominance of nematodes $P .(S$.) inopinatus and Camallanus sp. The host specificity is not an important factor in the distribution of $P$. (S.) inopinatus, a generalist nematode species that infects different wild fish species from Brazil. On the other hand, Salgado-Maldonado et al. (2016) stated that the distribution of helminths may reflect that of the tropical fish families they parasitize.

A similarity in the parasite component community in $C$. melanistius, $C$. spilurus, $C$. ephippifer and C. spilurus was found because they are wild host populations of the same environment. However, Krasnov et al. (2012) reported that the environmental dissimilarity between host 
TABLE II

Parasites in four species of Corydoras endemic to the eastern Amazon (Brazil).

\begin{tabular}{|c|c|c|c|c|c|c|}
\hline $\begin{array}{l}\text { Corydoras } \\
\text { ephippifer }\end{array}$ & & & & & & \\
\hline Indices & $\begin{array}{l}\text { Procamallanus } \\
\text { (S.) inopinatus }\end{array}$ & $\begin{array}{c}\text { Camallanus } \\
\text { sp. }\end{array}$ & Digenea & Digenea & $\begin{array}{c}\text { Gyrodactylus } \\
\text { sp. }\end{array}$ & Pentastomida \\
\hline Sites of infection & Intestine & Intestine & Gills & Intestine & Gills & Intestine \\
\hline Prevalence (\%) & 68.6 & 34.3 & 8.6 & 37.1 & 5.7 & 0 \\
\hline Mean intensity & 2.5 & 7.2 & 1.3 & 5.3 & 2 & 0 \\
\hline Mean abundance & 1.7 & 2.5 & 0.1 & 2.0 & 0.1 & 0 \\
\hline Range & $1-7$ & $1-22$ & $1-2$ & $1-19$ & $2-2$ & 0 \\
\hline $\begin{array}{c}\text { Total number of } \\
\text { parasites }\end{array}$ & 60 & 86 & 4 & 69 & 2 & 0 \\
\hline $\begin{array}{c}\text { Frequency of } \\
\text { dominance }\end{array}$ & 0.27 & 0.39 & 0.02 & 0.31 & 0.009 & 0 \\
\hline \multicolumn{7}{|l|}{$\begin{array}{c}\text { Corydoras } \\
\text { melanistius }\end{array}$} \\
\hline Sites of infection & Intestine & Intestine & Gills & Intestine & Gills & Intestine \\
\hline Prevalence (\%) & 26.5 & 40.8 & 16.3 & 24.5 & 0 & 0 \\
\hline Mean intensity & 3.0 & 3.2 & 1.0 & 1.2 & 0 & 0 \\
\hline Mean abundance & 0.8 & 1.3 & 0.2 & 1.3 & 0 & 0 \\
\hline Range & $1-9$ & $1-19$ & $1-1$ & $1-3$ & 0 & 0 \\
\hline $\begin{array}{l}\text { Total number of } \\
\text { parasites }\end{array}$ & 39 & 64 & 8 & 16 & 0 & 0 \\
\hline $\begin{array}{l}\text { Frequency of } \\
\text { dominance }\end{array}$ & 0.31 & 0.50 & 0.06 & 0.13 & 0 & 0 \\
\hline \multicolumn{7}{|l|}{$\begin{array}{c}\text { Corydoras } \\
\text { amapaensis }\end{array}$} \\
\hline Sites of infection & Intestine & Intestine & Gills & Intestine & Gills & Intestine \\
\hline Prevalence (\%) & 68.6 & 6.5 & 0 & 3.2 & 0 & 0 \\
\hline Mean intensity & 3.0 & 1.0 & 0 & 1.0 & 0 & 0 \\
\hline Mean abundance & 0.10 & 0.06 & 0 & 0.03 & 0 & 0 \\
\hline Range & $1-3$ & $1-1$ & 0 & $1-1$ & 0 & 0 \\
\hline $\begin{array}{l}\text { Total number of } \\
\text { parasites }\end{array}$ & 3 & 2 & 0 & 1 & 0 & 0 \\
\hline $\begin{array}{c}\text { Frequency of } \\
\text { dominance }\end{array}$ & 0.50 & 0.33 & 0 & 0.17 & 0 & 0 \\
\hline \multicolumn{7}{|l|}{$\begin{array}{c}\text { Corydoras } \\
\text { spilurus }\end{array}$} \\
\hline Sites of infection & Intestine & Intestine & Gills & Intestine & Gills & Intestine \\
\hline Prevalence (\%) & 77.4 & 67.7 & 0 & 25.8 & 0 & 3.2 \\
\hline Mean intensity & 2.8 & 11.1 & 0 & 9.50 & 0 & 1 \\
\hline Mean abundance & 2.2 & 7.5 & 0 & 2.5 & 0 & 0.03 \\
\hline Range & $1-9$ & $1-60$ & 0 & $1-32$ & 0 & 1 \\
\hline $\begin{array}{c}\text { Total number of } \\
\text { parasites }\end{array}$ & 67 & 234 & 0 & 76 & 0 & 1 \\
\hline $\begin{array}{c}\text { Frequency of } \\
\text { dominance }\end{array}$ & 0.18 & 0.62 & 0 & 0.20 & 0 & 0.003 \\
\hline
\end{tabular}


TABLE III

Index of dispersion (ID), $d$-statistic and discrepancy index (D) for the parasite infracommunities of four species of Corydoras endemic to the eastern Amazon (Brazil).

\begin{tabular}{|c|c|c|c|c|c|c|c|c|c|c|c|c|}
\hline \multirow{2}{*}{$\begin{array}{c}\text { Host fish } \\
\begin{array}{c}\text { Species of } \\
\text { parasites }\end{array}\end{array}$} & \multicolumn{3}{|c|}{ C. ephippifer } & \multicolumn{3}{|c|}{ C. melanistius } & \multicolumn{3}{|c|}{ C. spilurus } & \multicolumn{3}{|c|}{ C. amapaensis } \\
\hline & ID & $d$ & $\mathrm{D}$ & ID & $d$ & $\mathrm{D}$ & ID & $d$ & $\mathrm{D}$ & ID & $d$ & $\mathrm{D}$ \\
\hline $\begin{array}{l}\text { Procamallanus } \\
\text { (S.) inopinatus }\end{array}$ & 1.10 & 0.48 & 0.46 & 2.53 & 5.85 & 0.79 & 2.56 & 4.72 & 0.52 & 2.673 & 6.78 & 0.77 \\
\hline Camallanus sp. & 3.06 & 6.64 & 0.75 & 2.50 & 5.75 & 0.72 & 27.29 & 32.8 & 0.73 & - & - & - \\
\hline $\begin{array}{l}\text { Digenea gen. sp. } \\
\text { (intestine) }\end{array}$ & 1.75 & 2.72 & 0.69 & 1.12 & 0.61 & 0.82 & 17.29 & 24.52 & 0.84 & - & - & - \\
\hline $\begin{array}{l}\text { Digenea gen. sp. } \\
\text { (gills) }\end{array}$ & - & - & - & 0.85 & 0.69 & 0.78 & - & - & - & - & - & - \\
\hline
\end{tabular}

TABLE IV

Diversity descriptors and body parameters for parasite communities in four species of Corydoras endemic to the eastern Amazon (Brazil).

\begin{tabular}{ccccc}
\hline Parameters & C. ephippifer & C. melanistius & C. amapaensis & C. spilurus \\
\hline Weight $(\mathrm{g})$ & $2.7 \pm 0.9(1.3-4.8)$ & $2.2 \pm 0.4(1.6-3.3)$ & $5.9 \pm 1.7(2.6-8.6)$ & $3.6 \pm 1.01(1.83-5.5)$ \\
Length $(\mathrm{cm})$ & $5.5 \pm 0.6(4.6-6.8)$ & $4.8 \pm 0.3(4.03-5.5)$ & $7.1 \pm 0.7(5.6-8.2)$ & $5.8 \pm 0.6(4.8-6.8)$ \\
Parasite species richness & $1.51 \pm 0.89(0-3)$ & $1.08 \pm 0.98(0-4)$ & $0.13 \pm 0.43(0-2)$ & $1.74 \pm 0.73(0-3)$ \\
Shannon index & $0.26 \pm 0.34(0-1.05)$ & $0.19 \pm 0.35(0-1.31)$ & $0.022 \pm 0.12(0-0.69)$ & $0.36 \pm 0.33(0-1.76)$ \\
Evenness & $0.16 \pm 0.21(0-0.65)$ & $0.13 \pm 0.25(0-95)$ & $0.020 \pm 0.11(0-0.63)$ & $0.26 \pm 0.24(0-0.77)$ \\
\hline
\end{tabular}

TABLE V

Pairwise similarity index of parasite component community in four species of Corydoras endemic to the eastern Amazon (Brazil).

\begin{tabular}{ccccc}
\hline Pairwise & C. ephippifer & C. melanistius & C. amapaensis & C. spilurus \\
\hline C. ephippifer & \multicolumn{3}{c}{ Jaccard index } \\
C. melanistius & - & 0.75 & 0.75 & 0.60 \\
C. amapaensis & 0.75 & - & 0.75 & 0.80 \\
C. spilurus & 0.75 & 0.75 & - & 0.60 \\
\hline C. ephippifer & 0.75 & 0.80 & 0.75 & C. spilurus \\
\hline C. melanistius & C. melanistius & C. amapaensis & 0.72 \\
C. amapaensis & - & Bray-Curtis index & 0.05 & 0.44 \\
\hline
\end{tabular}


TABLE VI

List of parasites in wild populations of Corydoras spp. from different localities.

\begin{tabular}{|c|c|c|c|}
\hline Host fish & Parasite species & Locality & References \\
\hline \multirow{3}{*}{$\begin{array}{l}\text { Corydoras aeneus Gill, } \\
1858\end{array}$} & $\begin{array}{c}\text { Procamallanus (Spirocamallanus) pintoi } \\
\text { Kohn \& Fernandes, } 1988\end{array}$ & Venezuela & Moravec et al. (1997) \\
\hline & $\begin{array}{c}\text { Philocorydoras corydori Molnar, Hanek } \\
\text { et Fernando, } 1974\end{array}$ & Trinidad & Molnar et al. (1974) \\
\hline & $\begin{array}{c}\text { Philocorydoras margolisi Molnar, } \\
\text { Hanek et Fernando, } 1974\end{array}$ & Trinidad & Molnar et al. (1974) \\
\hline \multirow[t]{2}{*}{$\begin{array}{l}\text { Corydoras paleatus } \\
\text { Jenyns, } 1842\end{array}$} & \multirow{2}{*}{$\begin{array}{c}\text { Procamallanus (Spirocamallanus) pintoi } \\
\text { Kohn \& Fernandes, } 1988\end{array}$} & Brazil & $\begin{array}{l}\text { Kohn and Fernandes 1988, Moravec et } \\
\text { al. (1999), Ito et al. (2005) }\end{array}$ \\
\hline & & Peru & Moravec et al. (1999) \\
\hline $\begin{array}{l}\text { Corydoras reticulatus } \\
\text { Fraser-Brunner, } 1938\end{array}$ & $\begin{array}{c}\text { Piscinoodinium pillulare Schäperclaus, } \\
1954\end{array}$ & $\begin{array}{c}\text { Colombia, } \\
\text { Brazil }\end{array}$ & Ferraz and Sommerville (1998) \\
\hline \multirow{9}{*}{$\begin{array}{l}\text { Corydoras paleatus } \\
\text { Jenyns, } 1842\end{array}$} & $\begin{array}{c}\text { Neoechinorhynchus villoldoi } \\
\text { Vizcaíno, } 1992\end{array}$ & Argentina & Vizcaino (1992) \\
\hline & Lernaea cyprinacea Linnaeus, 1758 & Argentina & Plaul et al. (2010) \\
\hline & Philocorydoras platensis Suriano, 1986 & Argentina & Suriano (1986) \\
\hline & Gyrodactylus superbus Szidat, 1973 & Brazil & Popazoglo and Boeger (2000) \\
\hline & $\begin{array}{c}\text { Gyrodactylus samirae Papazoglo \& } \\
\text { Boeger, } 2000\end{array}$ & Brazil & Popazoglo and Boeger (2000) \\
\hline & \multirow{2}{*}{$\begin{array}{l}\text { Gyrodactylus anisopharynx Papazoglo } \\
\text { \& Boeger, } 2000\end{array}$} & Brazil & Popazoglo and Boeger (2000) \\
\hline & & Brazil & Bueno-Silva and Boeger (2009) \\
\hline & $\begin{array}{c}\text { Gyrodactylus corydori Bueno-Silva \& } \\
\text { Boeger, } 2009\end{array}$ & Brazil & Bueno-Silva and Boeger (2009) \\
\hline & $\begin{array}{c}\text { Trichodina corydori Marcotegui, } \\
\text { Basson \& Martorelli }\end{array}$ & Argentina & Marcotegui et al. (2016) \\
\hline \multirow{4}{*}{$\begin{array}{l}\text { Corydoras schwartzi } \\
\text { Rössel, } 1963\end{array}$} & $\begin{array}{l}\text { Gyrodactylus anisopharynx Popazoglo } \\
\text { \& Boeger, } 2000\end{array}$ & Brazil & Boeger et al. (2005) \\
\hline & $\begin{array}{l}\text { Gyrodactylus corydori Bueno-Silva \& } \\
\text { Boeger, } 2009\end{array}$ & Brazil & Bueno-Silva and Boeger (2009) \\
\hline & $\begin{array}{l}\text { Piscinoodinium pillulare Schäperclaus, } \\
1954\end{array}$ & $\begin{array}{l}\text { Colombia, } \\
\text { Brazil }\end{array}$ & Ferraz and Sommerville (1998) \\
\hline & Ascarophis sp. & Brazil & Moravec et al. (1999) \\
\hline \multirow{4}{*}{$\begin{array}{l}\text { Corydoras ehrhardti } \\
\text { Steindachner, } 1910\end{array}$} & Gyrodactylus superbus Szidat, 1973 & Brazil & Popazoglo and Boeger (2000) \\
\hline & $\begin{array}{c}\text { Gyrodactylus samirae Papazoglo \& } \\
\text { Boeger, } 2000\end{array}$ & Brazil & Popazoglo and Boeger (2000) \\
\hline & $\begin{array}{l}\text { Gyrodactylus anisopharynx Papazoglo } \\
\text { \& Boeger, } 2000\end{array}$ & Brazil & Bueno-Silva and Boeger (2009) \\
\hline & $\begin{array}{c}\text { Minilernaea floricapitella Thatcher \& } \\
\text { Huergo }\end{array}$ & Brazil & Tozato (2011) \\
\hline \multirow{2}{*}{$\begin{array}{l}\text { Corydoras melanistius } \\
\quad \text { Regan, } 1912\end{array}$} & $\begin{array}{l}\text { Silurodescoides exotica Rastogi, Mishra, } \\
\text { Rastogi, Sharmaand \& Singh, } 2008\end{array}$ & India & Rastogi et al. (2008) \\
\hline & $\begin{array}{l}\text { Piscinoodinium pillulare Schäperclaus, } \\
1954\end{array}$ & $\begin{array}{l}\text { Colombia, } \\
\text { Brazil }\end{array}$ & Ferraz and Sommerville (1998) \\
\hline \multirow{2}{*}{$\begin{array}{l}\text { Corydoras melini } \\
\text { Lönnberg \& Rendahl, } 1930\end{array}$} & $\begin{array}{l}\text { Myxidium amazonense Mathews, Silva, } \\
\text { Maia \& Adriano, } 2015\end{array}$ & Brazil & Mathews et al. (2015) \\
\hline & $\begin{array}{c}\text { Henneguya melini Mathews, Maia \& } \\
\text { Adriano, } 2016\end{array}$ & Brazil & Mathews et al. (2016) \\
\hline
\end{tabular}


TABLE VI (continuation)

\begin{tabular}{|c|c|c|c|}
\hline Host fish & Parasite species & Locality & References \\
\hline $\begin{array}{c}\text { Corydoras leucomelas } \\
\text { Eigenmann \& Allen, } 1942\end{array}$ & $\begin{array}{l}\text { Henneguya loreotoensis Mathews, } \\
\text { Naldoni \& Adriano, } 2017\end{array}$ & Peru & Mathews et al. (2017) \\
\hline $\begin{array}{l}\text { Corydoras agassizii } \\
\text { Steindachner, } 1876\end{array}$ & \multirow{4}{*}{$\begin{array}{l}\text { Piscinoodinium pillulare Schäperclaus, } \\
1954\end{array}$} & $\begin{array}{l}\text { Colombia, } \\
\text { Brazil }\end{array}$ & Ferraz and Sommerville (1998) \\
\hline $\begin{array}{l}\text { Corydoras arcuatus Elwin, } \\
1938\end{array}$ & & $\begin{array}{l}\text { Colombia } \\
\text { Brazil }\end{array}$ & Ferraz and Sommerville (1998) \\
\hline $\begin{array}{l}\text { Corydoras punctatus } \\
\text { Bloch, } 1794\end{array}$ & & $\begin{array}{l}\text { Colombia } \\
\text { and Brazil }\end{array}$ & Ferraz and Sommerville (1998) \\
\hline \multirow{2}{*}{$\begin{array}{l}\text { Corydoras metae } \\
\text { Eigenmann, } 1914\end{array}$} & & $\begin{array}{l}\text { Colombia } \\
\text { and Brazil }\end{array}$ & Ferraz and Sommerville (1998) \\
\hline & $\begin{array}{c}\text { Procamallanus (Spirocamallanus) pintoi } \\
\text { Kohn \& Fernandes, } 1988\end{array}$ & Colombia & Santana-Piñeros et al. (2017) \\
\hline $\begin{array}{c}\text { Corydoras sterbai Knaack, } \\
1962\end{array}$ & \multirow{7}{*}{$\begin{array}{c}\text { Piscinoodinium pillulare Schäperclaus, } \\
1954\end{array}$} & $\begin{array}{l}\text { Colombia } \\
\text { and Brazil }\end{array}$ & Ferraz and Sommerville (1998) \\
\hline $\begin{array}{l}\text { Corydoras robineae } \\
\text { Burgess, } 1983\end{array}$ & & $\begin{array}{l}\text { Colombia } \\
\text { and Brazil }\end{array}$ & Ferraz and Sommerville (1998) \\
\hline $\begin{array}{l}\text { Corydoras pygmaeus } \\
\text { Knaack, } 1966\end{array}$ & & $\begin{array}{l}\text { Colombia } \\
\text { and Brazil }\end{array}$ & Ferraz and Sommerville (1998) \\
\hline $\begin{array}{c}\text { Corydoras hastatus } \\
\text { Eigenmann \& Eigenmann, } \\
1888\end{array}$ & & $\begin{array}{l}\text { Colombia } \\
\text { and Brazil }\end{array}$ & Ferraz and Sommerville (1998) \\
\hline $\begin{array}{c}\text { Corydoras maculifer } \\
\text { Nijssen \& Isbrücker, } 1971\end{array}$ & & $\begin{array}{l}\text { Colombia, } \\
\text { Brazil }\end{array}$ & Ferraz and Sommerville (1998) \\
\hline $\begin{array}{l}\text { Corydoras elegans } \\
\text { Steindachner, } 1876\end{array}$ & & $\begin{array}{l}\text { Colombia, } \\
\text { Brazil }\end{array}$ & Ferraz and Sommerville (1998) \\
\hline $\begin{array}{c}\text { Corydoras haraldschultzi } \\
\text { Knaack, } 1962\end{array}$ & & $\begin{array}{l}\text { Colombia, } \\
\text { Brazil }\end{array}$ & Ferraz and Sommerville (1998) \\
\hline $\begin{array}{c}\text { Corydoras julii } \\
\text { Steindachner, } 1906\end{array}$ & Neoechinorhynchus sp. & Brazil & Moravec et al. (1999) \\
\hline
\end{tabular}

populations are the best predictors of dissimilarity between parasite faunas. Infracommunities with low rates of colonization, low numbers of species and individuals, and with low or no interspecific interactions is a common pattern in freshwater fish populations (Bautista-Hernández et al. 2014). The species richness of parasites, Shannon diversity index and evenness were lowest in $C$. amapaensis compared to C. ephippifer, C. melanistius and C. spilurus, which had few ectoparasites and a predominance of endoparasites. This higher diversity of endoparasites $(P$. $(S$.) inopinatus and Camallanus sp.) seems to reflect environmental conditions that were favorable to the transmission of parasites, which require intermediate hosts.
Moreover, this predominance of endoparasites may be related to the life style of these omnivorous fish that occupy low levels in the food web, feeding mainly on invertebrates, such as aquatic worms, microcrustaceans, insects, larvae, insect eggs and mollusks (Froese and Pauly 2018).

A fundamental aspect of the host-parasite interaction is related to the distribution pattern of parasites among hosts. The distribution of parasites in freshwater fish is typically aggregated (Guidelli et al. 2003, Poulin 2013, Amarante et al. 2015, Oliveira and Tavares-Dias 2016). The aggregated dispersion of parasites has been attributed to the heterogeneity of the environment and to susceptibility of the host population to the parasites 
(Poulin 2013). Thus, aggregated dispersion pattern of parasites in C. ephippifer, C. melanistius and $C$. spilurus was found, as expected. In contrast, the dispersion of $P$. (S.) inopinatus in $C$. ephippifer was random, a distribution pattern that occurs mainly in parasite species with moderate or high pathogenicity and with low ability for colonizing hosts in environments (Guidelli et al. 2003, Oliveira and Tavares-Dias 2016).

In the Neotropical region, 39 species of Gyrodactylidae of 18 Gyrodactylus are known (Bueno-Silva and Boeger 2009). Gyrodactylids exhibit extraordinary species diversity and broad host range, because this evolutionary success is associated with a suite of morphological and life-history traits that include, in part, continuous transmission, i.e., ability to infect new hosts throughout their direct life cycle (Boeger et al. 2005). Monogeneans Gyrodactylus sp. were found only in the gills of $C$. ephippifer and at low levels of infection. Usually, these low levels of monogeneans in wild fish are not pathogenic, since they seem to be in balance with their hosts. Gyrodactylus anisopharynx, G. corydori, $G$. superbus, G. samirae are known species of monogeneans infecting Corydoras spp. (Table VI). However, these ectoparasites of C. ephippifer do not seem any of these species of monogeneans.

Pentastomid are endoparasites mainly of crocodilian reptiles and aquatic turtles, their main definitive hosts. Fish are intermediate hosts for those species that infect such reptiles (Giesen et al. 2013, Christoffersen and Assis 2013). Only one pentastomid larva was found in the intestine of $C$. spilurus and that may be accidental. However, the infection levels of these endoparasites vary among host fish species (Giesen et al. 2013). Although the pentastomid species was not identified, Giesen et al. (2013) reported that two Sebekidae genera from fish intermediate hosts are known for Brazil: Leiperia gracilis Diesing, 1836 and Sebekia oxycephala Diesing, 1835, which infected species of Serrasalmidae, Erythrinidae, Pimelodidae and Poeciliidae. However, the pentastomid of $C$. spilurus seem be of the genus Sebekia. Abiotic and biotic factors have been also associated with the diversity and abundance of helminths in wild fish populations (Bautista-Hernández et al. 2014, Salgado-Maldonado et al. 2016, Oliveira and Tavares-Dias 2016).

Undetermined digenean metacercariae occurred in gills and intestine of hosts in this study and at low infection levels. To the best of our knowledge, no digenean species has been reported for Corydoras spp. (Table VI). However, in C. melanistius, C. ephippifer and C. spilurus, the highest infection rates were caused by $P$. $(S$.) inopinatus and Camallanus sp. These infection levels by $P$. (S.) inopinatus were similar to those reported for $C$. paleatus infected by $P$. $(S$.) pintoi (Ito et al. 2005). In contrast, the infection levels were higher than that of $P$. (S.) pintoi in $C$. aeneus from Venezuela (Moravec et al. 1997) and in $C$. paleatus from the Paraná River (Moravec et al. 1999). Nevertheless, these are different congeneric hosts collected in different ecosystems, which has different environmental conditions.

The abundance of parasites is an important factor that can reduce the weight and length of host fish populations, affecting the body conditions of them (Guidelli et al. 2003, Rolbiecki 2006). No correlation between host length and abundance of parasites was found for C. ephippifer, $C$. melanistius, C. spilurus and C. amapaensis; probably due to the little variation in the length of the hosts. Ito et al. (2005) also reported no correlation between the infection intensity of $P$. $(S$.) pinto $i$ with the body length of $C$. paleatus from the Paraná River. This absence of correlation between the host length with the parasites abundance may be indicative that the length of these hosts does not in fact influence the variation in the parasite infracommunities. Nevertheless, correlation between parasites abundance with host body size 
is far from universal. The host size can either be related or not to its age, once the parasitic population may increase, decrease or not suffer effect from its size and age (Guidelli et al. 2003, Rolbiecki 2006, Oliveira and Tavares-Dias 2016).

\section{CONCLUSIONS}

Parasite communities of $C$. ephippifer, $C$. melanistius, C. spilurus and C. amapaensis were characterized by a high similarity, low species richness, low diversity, low evenness, and composed mainly of endoparasites with high prevalence, low abundance and overdispersion. In these hosts, concurrent infections with two endohelminth parasites were a common occurrence. An important component in the determination of the helminth parasite community composition was the dominance of species that use fish as secondary intermediate or paratenic hosts. Finally, given the importance of ornamental fish as a source of income for people living in this study area, and a possible negative impact of parasites on fish, studies on control and treatment of endoparasite species are necessary.

\section{ACKNOWLEDGMENTS}

Dr. M. Tavares-Dias was granted a Research Fellowship (\# 303013/2015-0) from the Conselho Nacional de Desenvolvimento Científico e Tecnológico (CNPq, Brazil).

\section{REFERENCES}

AGUINAGA JY, MARCUSSO PF, CLAUDIANO GS, LIMA BTM, SEBASTIÃO FA, FERNANDES JBK, MORAES FR AND MORAES JRE. 2015. Parasitic infections in ornamental cichlid fish in the Peruvian Amazon. Braz J Vet Parasitol 24(1): 82-86.

AMARANTE CF, TASSINARI WS, LUQUE JL AND PEREIRA MJS. 2015. Factors associated with parasite aggregation levels in fishes from Brazil. Braz J Vet Parasitol 24: 174-182.

BAUTISTA-HERNÁNDEZ CE, VIOLANTE-GONZÁLEZ J, MONKS S AND PULIDO-FLORES G. 2014.
Helminth communities of Xiphophorus malinche (Pisces: Poeciliidae), endemic freshwater fish from the Pánuco River, Hidalgo, Mexico. Rev Mex Biodiver 85: 838-844.

BOEGER WA, KRITSKY DC, PIE MR AND ENGERS KB. 2005. Mode of transmission, host switching, and escape from the red queen by viviparous gyrodactylids (Monogenoidea). J Parasitol 91: 1000-1007.

BUENO-SILVA MN AND BOEGER WA. 2009. Neotropical Monogenoidea. 53. Gyrodactylus corydori sp. n. and redescription of Gyrodactylus anisopharynx (Gyrodactylidea: Gyrodactylidae), parasites of Corydoras spp. (Siluriformes: Callichthyidae) from southern Brazil. Folia Parasitol 56: 13-20.

BUSH AO, LAFFERTY KD, LOTZ JM AND SHOSTAK W. 1997. Parasitology meets ecology on its own terms: Margolis et al. revisited. J. Parasitol 83: 575-583.

CHRISTOFFERSEN ML AND DE ASSIS JE. 2013. A systematic monograph of the recent Pentastomida, with a compilation of their hosts. Zool Meded 87: 1-206.

EIRAS JC, TAKEMOTO RM AND PAVANELLI GC. 2006. Métodos de estudos e técnicas laboratoriais em parasitologia de peixes. Maringá: Eduem, 199 p.

FERRAZ E. 1999. Management and diseases of the ornamental fish exported from the Rio Negro basin. In: Val AL and Val VMFA (Eds), Biology of tropical fishes. INPA, Manaus, p. 99-111.

FERRAZ E AND SOMMERVILLE C. 1998. Pathology of Piscinoodinium sp. (Protozoa: Dinoflagellida), parasites of the ornamental freshwater catfishes Corydoras spp. and Brochis splendens (Pisces: Callichthydae). Dis Aquatic Org 33: 43-49.

FROESE R AND PAULY D. 2018. FishBase. Available at: www.fishbase.org. Accessed on February, 2018.

GIESEN SC, TAKEMOTO RM, CALITZ F, LIZAMA MAP AND JUNKER K. 2013. Infective pentastomid larvae from Pygocentrus nattereri Kner (Pisces, Characidae) from the Miranda River, Pantanal, Mato Grosso do Sul State, Brazil, with notes on their taxonomy and epidemiology. Folia Parasitol 60: 457-468.

GUIDELLI GM, ISAAC A, TAKEMOTO RM AND PAVANELLI GC. 2003. Endoparasite infracommunities of Hemisorubim platyrhynchos (Valenciennes, 1840) (Pisces: Pimelodidae) of the Baía River, upper Paraná River floodplain, Brazil: specific composition and ecological aspects. Braz J Biol 63: 261-268.

HAMMER O, HARPER DAT AND RYAN PD. 2001. PAST: paleontological statistics software package for education and data analysis. Palaeontol Electron 4: 1-9.

HOSHINO EM, HOSHINO MDFG AND TAVARES-DIAS M. 2018. Parasites of ornamental fish commercialized in Macapá, Amapá State (Brazil). Braz J Vet Parasitol 27: 75-80. 
ITO KF, MOREIRA ST, TAKEMOTO RM AND PAVANELLI GC. 2005. Ecological aspects of the Procamallanus (Spirocamallanus) pintoi parasite of Corydoras paleatus (Jenyns, 1842) (Siluriformes: Callichthyidae) in reservoirs of the State of Paraná, Brazil. Acta Sci Biol Sci 27: 239242.

KOHN A AND FERNANDES BMM. 1988. Helminth parasites of fishes from the hydroelectric power station of Eletrosul (Brazil). I. Procamallanus petterae n. sp. and Spirocamallanus pintoi $\mathrm{n}$. sp. (Nematoda, Camallanidae) from the reservoir of "Salto Osório". Mem Inst Oswaldo Cruz 83: 293-298.

KRASNOV BR, FORTUNA MA, MOUILLOT D, KHOKHLOVA IS, SHENBROT GI AND POULIN R. 2012. Phylogenetic signal in module composition and species connectivity in compartmentalized host-parasite networks. Am Nat 179: 501-511.

LUDWIG J AND REYNOLDS JF. 1988. Statistical ecology: a primer on methods and computing. New York: WileyInterscience, $337 \mathrm{p}$.

MAGURRAN AE. 2004. Measuring biological diversity. Oxford: Blackwell Science, 266 p.

MARCOTEGUI PS, BASSON L AND MARTORELLI SR. 2016. Trichodinids (Ciliophora) of Corydoras paleatus (Siluriformes) and Jenynsia multidentata (Cyprinodontiformes) from Argentina, with description of Trichodina corydori n. sp. and Trichodina jenynsii n. sp. Acta Protozool 55: 249-257.

MATHEWS PD, MAIA AAM AND ADRIANO EA. 2016. Henneguya melini n. sp. (Myxosporea: Myxobolidae), a parasite of Corydoras melini (Teleostei: Siluriformes) in the Amazon region: morphological and ultrastructural aspects. Parasitol Res 115: 3599-3604.

MATHEWS PD, NALDONI J AND ADRIANO EA. 2017. Morphology and small subunit rDNA-based phylogeny of a new Henneguya species, infecting the ornamental fish Corydoras leucomelas from the Peruvian Amazon. Acta Trop 176: 51-57.

MATHEWS PD, SILVA MRM, MAIA AAM AND ADRIANO EA. 2015. Ultrastructure and ssrRNA sequencing of Myxidium amazonense $\mathrm{n}$. sp. a myxosporean parasite of Corydoras melini from the Rio Negro River, Amazonas State, Brazil. Parasitol Res 114: 4675-4683.

MOLNAR K, HANEK G AND FERNANDO CH. 1974. Ancyrocephalids (Monogenea) from freshwater fishes of Trinidad. J Parasitol 60(6): 914-920.

MORAVEC F, PROUZA A AND ROYERO R. 1997. Some nematodes of freshwater fishes in Venezuela. Folia Parasitol 44: 33-47.

MORAVEC F, WOLTER J AND KÖRTING W. 1999. Some nematodes and acanthocephalans from exotic ornamental freshwater fishes imported into Germany. Folia Parasitol 46: 296-310.
OLIVEIRA MSB AND TAVARES-DIAS M. 2016. Communities of parasites metazoans Piaractus brachypomus (Pisces, Serrasalmidae) in the lower Amazon River (Brazil). Braz J Vet Parasitol 25: 151-157.

PLAUL SE, ROMERO NG AND BARBEITO CG. 2010. Distribution of the exotic parasite, Lernaea cyprinacea (Copepoda, Lernaeidae) in Argentina. Bull Eur Assoc Fish Pathol 30: 65-73.

POPAZOGLO F AND BOEGER WA. 2000. Neotropical Monogenoidea 37. Redescription of Gyrodactylus superbus (Szidat, 1973) comb. n. and description of two new species of Gyrodactylus (Gyrodactylidea: Gyrodactylidae) from Corydoras paleatus and C. ehrhardti (Teleostei: Siluriformes: Callichthyidae) of Southern Brazil. Folia Parasitol 47: 105-110.

POULIN R. 2013. Explaining variability in parasite aggregation levels among host samples. Parasitology 140: 541-546.

RASTOGI P, MISHRA D, RASTOGI R, SHARMA V AND SINGH HS. 2008. On a new species of genus Silurodescoides (Achmerow, 1964) Gussev, 1973 with redescription, copulation biology and neuroanatomy of $S$. vistulensis (New Combination) from Meerut (U.P.), India. Asian J Experim Sci 22: 329-342.

RODRÍGUEZ-ITHURRALDE D, DEL PUERTO R AND FERNÁNDEZ-BORNIA F. 2014. Morphological development of Corydoras aff. paleatus (Siluriformes, Callichthyidae) and correlation with the emergence of motor and social behaviors. Iheringia (Série Zoologia) 104: 189-199.

ROHDE K, HAYWARD C AND HEAP M. 1995. Aspects of the ecology of metazoan ectoparasites of marine fishes. Int J Parasitol 25: 945-970.

ROLBIECKI L. 2006. Correlation between the occurrence of parasites and body length of roach, carp bream, European perch, zander, and ruffe in the Vistula Lagoon estuary. Oceanol Hydrobiol Stud 35: 257-267.

RÓZSA L, REICZIGEL J AND MAJOROS G. 2000. Quantifying parasites in samples of hosts. J Parasitol 86: 228-232.

SALGADO-MALDONADO G, NOVELO-TURCOTTE MT, CASPETA-MANDUJANO JM, VAZQUEZ-HURTADO G, QUIROZ-MARTÍNEZ B, MERCADO-SILVA N AND FAVILA M. 2016. Host specificity and the structure of helminth parasite communities of fishes in a Neotropical river in Mexico. Parasite 23: 1-10.

SANTANA-PIÑEROS AM, CRUZ-QUINTANA Y AND OLAYA VO. 2017. Parámetros de infección de Procamallanus (Spirocamallanus) cf. pintoi en Corydoras metae de Villavicencio, Colombia. Revista La Técnica 18: 49-57.

SURIANO DM. 1986. Philocorydoras platensis gen. n. et sp. n. (Monogenea: Ancyrocephalidae) from Corydoras paleatus 
(Jenyns) (Pisces: Callichthyidae) in Laguna Chascomus Republica Argentina. Helminthologia 23: 249-256.

TAVARES-DIAS M, LEMOS JRG AND MARTINS ML. 2010. Parasitic fauna of eight species of ornamental freshwater fish species from the middle Negro River in the Brazilian Amazon region. Rev Brasil Parasitol Vet 19: 103-107.

TENCATT LFC AND OHARA WM. 2016. Two new species of Corydoras Lacépède, 1803 (Siluriformes: Callichthyidae) from the Rio Madeira basin, Brazil. Neotrop Ichthyol 14: e150063.
TOZATO HC. 2011. Influência do parasitismo na condição de Corydoras aeneus (Gill, 1858) (Osteichthyes: Siluriformes) da bacia do Ribeirão do Feijão, São Carlos, SP. Rev Cien Eletron Med Vet 19: 1-15.

VIZCAINO SI. 1992. Especie nueva del genero Neoechinorhynchus (Acanthocephala, Neoechinorhynchidae) parasita de peces de Argentina. Anales Inst Biol Univ Nac Auton Mexico 63: 179-184.

ZAR JH. 2010. Biostatistical analysis. $5^{\text {th }}$ ed., New Jersey: Prentice Hall, 944 p. 